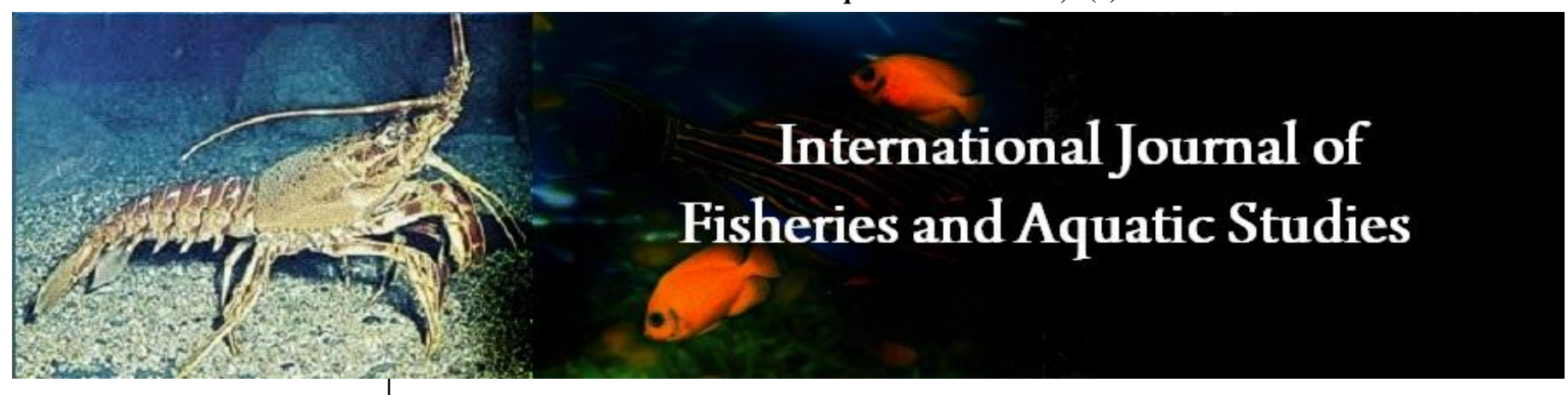

E-ISSN: 2347-5129

P-ISSN: 2394-0506

(ICV-Poland) Impact Value: 5.62

(GIF) Impact Factor: 0.549

IJFAS 2018; 6(3): 128-133

(C) 2018 IJFAS

www.fisheriesjournal.com

Received: 20-03-2018

Accepted: 24-04-2018

Sushma Singh

Department of Environmental

Sciences, H.N.B. Garhwal

University (A Central

University), Srinagar-Garhwal,

Uttarakhand India

Ramesh C Sharma

Department of Environmental

Sciences, H.N.B. Garhwal

University (A Central

University), Srinagar-Garhwal,

Uttarakhand India
Correspondence

Sushma Singh

Department of Environmental

Sciences, H.N.B. Garhwal

University (A Central

University), Srinagar-Garhwal,

Uttarakhand India

\section{Monitoring of algal taxa as bioindicator for assessing the health of the high altitude wetland, Dodi Tal, Garhwal Himalaya, India}

\author{
Sushma Singh and Ramesh C Sharma
}

\begin{abstract}
The present study has been carried out on the algal taxa of high altitude wetland, Dodi Tal (3,075 above m.s.1), located in the western Himalaya, India. A total of 47 taxa belonging to 43 genera of phytoplankton were represented by four classes, viz., Bacillariophyceae (20 genera), Chlorophyceae (16 genera), Cyanophyceae (4 genera) and Dinophyceae (3genera). The Palmer, Algal Genus and Species Pollution Index were employed to study the water quality of high altitude lake Dodi Tal. The total scores of $S_{1}$ and $S_{2}$ showed 10 indicating probable Lack of organic pollution while $S_{3}$ and $S_{4}$ showed moderate pollution due to tourist influx. Shannon wiener diversity index was recorded to be diversity index was recorded to be maximum (4.11) in summer and minimum (3.59) in monsoon, Thus, algal taxa can be considered as good bioindicator for assessing the health of the high altitude wetlands.
\end{abstract}

Keywords: Algal taxa, high altitude wetland, pollution index, evenness, Shannon wiener diversity

\section{Introduction}

High altitude wetlands are an important category of wetland found in the higher reaches of the Garhwal Himalaya. Algal communities do not respond only to natural changes into the lakes, but may also present variations as a consequence of human interventions affecting the water body, either directly or through activities carried on in the basin as a whole Ganai and Praveen

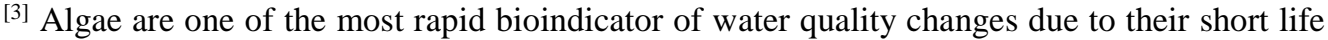
spans, quick response to pollutants and easy to determine their numbers Plafkin et al. ${ }^{[11]}$. Ganai and Praveen ${ }^{[3]}$ recorded phytoplankton (algal) species as indicators of water quality The high altitude lakes are mostly located in the higher reaches and are inaccessible. Environmental baseline data are fragmentary of these high altitude wetlands of Uttarakhand. No sincere effort has been made for studying these wetlands. Therefore, it was felt desirable to undertake study on the monitoring of algal taxa as bioindicator for assessment the health of high altitude wetland of Dodi Tal of Western Himalaya.

\section{Materials and methods}

\section{1 study area}

A high altitude wetland, Dodi Tal is very important freshwater ecosystem of the Garhwal Himalaya. It is located between latitude $30^{\circ} 52^{\prime} 31.99 \mathrm{~N}$ and longitude $78^{\circ} 31^{\prime} 12.47^{\prime \prime} \mathrm{E}$ at an altitude of 3,075 m.asl in Uttarkashi district, Uttarakhand, India. It is large, somewhat triangular shaped lake with an approximate length of $248.22 \mathrm{~m}$, width of $151.99 \mathrm{~m}$ and depth of $19.97 \mathrm{~m}$ with a catchment area of about 3.0623 ha, Dodi Tal receives water from precipitation and melting of snow. (Fig. 1).

\subsection{Collection of sample and Analysis}

The present study on algal taxa was undertaken from November 2014-October 2015 four different sites $\left(S_{1}, S_{2}, S_{3}\right.$ and $\left.S_{4}\right)$ For algal taxa, plankton net of mesh size $20 \mu \mathrm{m}$ and immediately preserved in water sample bottle containing $4 \%$ formalin solution and identification was done with the help of inverted compound microscope Olympus CH 20i.For rating the water sample as high or low organically polluted, the Algal Genus Pollution Index (AGPI) of Palmer [11] was employed. Palmer ${ }^{[11]}$ formulated the pollution index scale for assessment of organic pollution of the water bodies Enumeration of the algal taxa was done by 
taking $1 \mathrm{ml}$ of the sub- sample in the Sedgwick Rafter chamber counting its entire contents under microscope to obtain the statistical accuracy after their identification with the help of standard taxonomical works (Edmondson [2] APHA ${ }^{[1]}$ Perscotte ${ }^{[13]}$ Munshi et al. $\left.{ }^{[9]}\right)$. Shannon Wiener Diversity Indices: Species diversity index $(\bar{H})$ was calculated using the Shannon Wiener information function (Shannon and Weiner ${ }^{[15]}$. The evenness was calculated using Eveness index of Jaccard ${ }^{[5]}$.

\section{Results and Discussion}

\subsection{Algal taxa community structure}

A total of 47 taxa belonging to 43 genera of phytoplankton were represented by four classes, viz., Bacillariophyceae (20 genera), Chlorophyceae (16 genera), Cyanophyceae (4 genera) and Dinophyceae (3genera) Table. 2. The percentage compositions of these four families were Bacillariophyceae (47\%), Chlorophyceae (37\%), Cyanophyceae (9\%), and Dinophyceae (7\%) in high altitude wetland Dodi Tal. (Fig. 2). Similar finding has been reported phytoplankton (14) Bacillariophyceae, Chlorophyceae, Cyanophyceae and Dyanophyceae was recorded contributing 55\%, 30\%, 10\% and $5 \%$ respectively in Kailash Lake, Kashmir Naik et al. ${ }^{[10]}$. Rawat and Sharma ${ }^{[14]}$ reported 36 species of phytoplankton belonging to four groups, viz, Chlorophyceae, Bacillariophycea, Dinophyceae, Cyanophycea in Deoria Tal, Uttarakhand. Maximum density (1283 ind. ${ }^{-1}$ ), of algal taxa was recorded in April at $\mathrm{S}_{4}$ and minimum (239 ind. $\mathrm{l}^{-1}$ ) in January at $S_{2}$ and seasonally it was found to be maximum $\left(1186 \pm 282.50\right.$ ind. $\left.^{-1}\right)$ in autumn at S3 and minimum $\left(381.5 \pm 58.5\right.$ ind. $\left.1^{-1}\right)$ in monsoon at $\mathrm{S}_{1}$. The abundance of Bacillariophyceae in cold regions is due to the fact that they are able to grow in conditions of weak light and low temperature which are less suitable for other algae Loffler [8] in Mt Everest high altitude lake, Nepal. The density of Bacillariophyceae was found to be maximum (912 ind. $\left.{ }^{-1}\right)$ at $\mathrm{S}_{1}$ and minimum (92 ind. $\mathrm{l}^{-1}$ ) at $\mathrm{S}_{4}$. The most dominant species were Fragilaria sp., Navicula sp., Cyclotella sp., Synedra ulna, Nitzschia sp., Cymbella sp. Cladophora sp., in high altitude lake, Dodi Tal. Similar finding in Kailash Lake, Kashmir Naik et al., ${ }^{[10]}$; Kumar et al., ${ }^{[7]}$ in Badrinath Ponds, Uttarakhand. Members of Bacillariophyceae can be used as bio-indicator for water quality evaluation, Stevenson and Pan [17]; Goma et al. [4]. Synedra ulna can produce both unwanted taste and odour problems in drinking waters and, when in large number, clog filters Palmer [11]. Chlorophyceae was also found to be an important contributor (35\% -36\%) of the phytoplankton community of Dodi Tal Scenedesmus quadricauda, Closterium spp., Pandorina morum, Zygnema spp., Zygnema spp. Spirogyra spp.,. were found to be the dominant species. Scenedesmus quadricauda abundant may impart unwanted odours to drinking waters (Palmer, 1969). The density of Chlorophyceae was found to be maximum (819 ind. $\left.^{-1}\right)$ at $\mathrm{S}_{3}$ and minimum (111 ind.1 $\left.{ }^{-1}\right)$ at $\mathrm{S}_{2}$. Cyanophyceae was found to be contribute (9\%) of the phytoplankton community of Dodi Tal. Cyanophyceae Anabena $s p$. and Ocillatoria $s p$. were also recorded in Dodi Tal. Similar species has been reported in Bhimtal, Uttarakhand by Jindal et al., ${ }^{[6]}$ in Rewalsar lake, Himachal Pradesh; Singh et al., ${ }^{[16]}$ in Chandra Tal, Suraj Tal, Deepak Tal and Sissu lake in Lahaul Spiti, Himachal Pradesh. In Palmer's pollution index of algal genera Anabaena was not considered as pollution tolerant. The density of Cyanophyceae was found to be maximum (39 ind. $1^{-1}$ ) at $S_{4}$ and minimum (3.00 ind. $1^{-1}$ ) at $S_{1}$. Dinophyceae was found to be contribute $(6 \%)$ of the phytoplankton community of Dodi Tal. The density of Dinophyceae was found to be maximum (185 ind.1 - $^{-}$ $\left.{ }^{1}\right)$ at $S_{4}$ and minimum $\left(24\right.$ ind. $\left.1^{-1}\right)$ at $S_{1}$ (Fig. 2).

\subsection{Palmer's pollution index}

Palmer [11] first made the list of algae genera and species which indicate organic pollution. According to Palmer, scores of 20 or more are indication of high organic pollution. The pollution tolerant genera belonging to four groups of algae from four sites of Dodi Tal was recorded (Table 2). By using Palmer's index of pollution for rating of water samples as high, moderate and low organically polluted at four sites of Dodi Tal were tested. The total score of Algal Genus Pollution Index (AGPI) of sites $\mathrm{S} 2<\mathrm{S} 1<<\mathrm{S}_{3}<\mathrm{S}_{4}$ were calculated to be 10, 7, 11 and 12 respectively (Table 2 and Fig. $3)$. The total score of Algal species Pollution Index of sites $\mathrm{S} 2<\mathrm{S} 1<<\mathrm{S}_{3}<\mathrm{S}_{4}$ were calculated to be $10,4,13$ and 13 respectively (Table 3 and Fig 3 ). The total scores of $S_{1}$ and $S_{2}$ showed 10 indicating probable Lack of organic pollution while $S_{3}$ and $S_{4}$ showed moderate pollution due to tourist influx according to Palmer ${ }^{[11]}$ (Table 1-3), Oscillatoria was found to be the most active participant in all sites which may be the good indicator of contaminated water the similar observation recorded by Palmer ${ }^{[11]}$.Scenedesmus, Navicula, Nitzschia, Synedra and Melosira were recorded repeatedly and consider as indicators of pollution in view of the results of Palmer pollution index.

\subsection{Shannon Wiener index}

Wilhm and Dorris ${ }^{[18]}$ set diversity index $<1$ for highly polluted, 1-3 for moderately polluted and $>4$ for unpolluted water bodies. the Shannon-Weiner diversity index in the present study ranged between 3.27-4.34 in the high altitude wetland, Dodi Tal, Seasonally diversity index was recorded to be maximum (4.11) in summer and minimum (3.59) in monsoon. Therefore, this water body comes in diversity index (>4) means clean water. Table. 4 . So here we found the water of the high altitude wetland, Dodi Tal is clean and potable.

\subsection{Jaccard's Eveness index}

The data on Jaccard's eveness calculated for algal taxa dwelling in the high altitude wetland, Dodi Tal Table. It was recorded to be maximum (0.150) at $S_{2}$ and minimum (0.092) at $S_{1}$ and $S_{3}$. Seasonally, Jaccard's eveness was found to be maximum (0.139) in monsoon season at $S_{2}$ and minimum $(0.099)$ in autumn and summer seasons at $S_{3}$ and $S_{4}$ during the year of the study (Table 5).

\section{Conclusion}

Over all pollution indexes was showed that all sites of the lake water showed confirms low organic pollution and Palmer (1969) suggested that algae are reliable indicators of water pollution as it was justify in present study. Diversity change of algal communities (Palmer algal genus and species index) can be used to compare and classify the water quality of High altitude wetland Dodi Tal of Uttarakhand. We recommend that a sustainable management plan should be formulated and implemented in order to preserve Dodi Tal's diverse ecosystem. 
Table 1: Algal genus pollution index (Palmer, 1969).

\begin{tabular}{|c|c|c|c|}
\hline Genus & Pollution Index & Species & Pollution index \\
\hline Anacystis & 1 & Ankistrodesmus falcatus & 3 \\
\hline Ankistrodesmus & 2 & Arthrospirajenneri & 2 \\
\hline Chlamydomonas & 4 & Chlorella vulgaris & 2 \\
\hline Chlorella & 3 & Cyclotellameneghiniana & 2 \\
\hline Closterium & 1 & Euglena gracilis & 1 \\
\hline Cyclotella & 1 & Euglena viridis & 6 \\
\hline Euglena & 5 & Gomphonema parvulum & 1 \\
\hline Gomphonema & 1 & Melosira varians & 2 \\
\hline Lepocinclis & 1 & Navicula crptocaphala & 1 \\
\hline Melosira & 1 & Nitzschia acicularis & 1 \\
\hline Micractinium & 1 & Nitzschia palea & 5 \\
\hline Navicula & 3 & Oscillatoria chlorine & 2 \\
\hline Nitzschia & 3 & Oscillatoria limosa & 4 \\
\hline Oscillatoria & 5 & Oscillatoria princeps & 1 \\
\hline Pandorina & 1 & Oscillatoria putrid & 1 \\
\hline Phacus & 2 & Oscillatoriatenuis & 4 \\
\hline Phormidium & 1 & Pandorina morum & 3 \\
\hline Scenedesmus & 4 & Scenedesmus quadricauda & 4 \\
\hline Stigeoclonium & 2 & Stigeocloniumtenue & 3 \\
\hline Synedra & 2 & Synedra ulna & 3 \\
\hline
\end{tabular}

Following numerical values for pollution classification of Palmer (1969), 0-10= Lack of organic pollution $10-15=$ Moderate pollution $15-20=$ Probable high organic pollution 20 or more $=$ Confirms high organic pollution

Table 2: Pollution index of Algal genera according to Palmer, (1969) at four sites of high altitude wetland Dodi Tal of Garhwal Himalaya 2014 $-2015$.

\begin{tabular}{|c|c|c|c|c|c|c|c|}
\hline Bacillariophyceae & Order & Family & Pollution Index (Palmer1969) & S1 & S2 & S3 & S4 \\
\hline Achananthes Sp. & Pennales & Acanthaceae & - & - & + & + & + \\
\hline Amphora spp. & Pennales & Naviculaceae & - & - & - & + & + \\
\hline Asterionella spp. & & & - & - & + & + & + \\
\hline \multicolumn{8}{|l|}{ Bacillaria spp. } \\
\hline Cyclotella spp. & Centrales & Coscinodiscaceae & 1 & $+(1)$ & $+(1)$ & $+(1)$ & $+(1)$ \\
\hline Frustulia spp. & & & - & + & + & + & + \\
\hline Gomphonema spp. & Pennales & Naviculaceae & 1 & - & $+(1)$ & - & $+(1)$ \\
\hline Melosira spp. & Centrales & Coscinodiscaceae & 1 & $+(1)$ & $+(1)$ & $+(1)$ & $+(1)$ \\
\hline Navicula spp. & Pennales & Naviculaceae & 3 & $+(3)$ & $+(3)$ & $+(3)$ & $+(3)$ \\
\hline \multicolumn{8}{|l|}{ Chlorophyceae } \\
\hline Cosmarium spp. & Zygnamatales & Mesotaeniaceae & - & + & - & + & + \\
\hline Closterium spp. & Zygnamatales & Mesotaeniaceae & 1 & - & $+(1)$ & $+(1)$ & $+(1)$ \\
\hline Mougeotia Spp. & Zygnematales & zygnemataceae & - & + & + & + & + \\
\hline Oocystis spp. & - & Occystaceae & - & - & - & + & - \\
\hline Pediastrum spp. & - & Hydrodictyaceae & - & + & - & + & + \\
\hline Spirogyra spp. & Zygnematales & zygnemataceae & - & + & + & + & + \\
\hline Staurastrum spp. & Zygnamatales & Mesotaeniaceae & - & + & - & + & - \\
\hline Zygnema spp. & Zygnematales & zygnemataceae & - & + & + & + & + \\
\hline \multicolumn{8}{|l|}{ Cyanophyceae } \\
\hline Anabaena sp. & - & - & & + & - & + & + \\
\hline Lyngbya sp. & - & - & - & + & - & + & + \\
\hline Oscillatoria sp. & - & Cyanophyceae & 5 & $+(5)$ & - & $+(5)$ & $+(5)$ \\
\hline Spirulina sp. & - & Cyanophyceae & - & + & - & - & - \\
\hline \multicolumn{8}{|l|}{ Dinophyceae } \\
\hline Ceratium spp. & Peridiniales & Ceratiaceae & - & + & + & - & + \\
\hline Asterocystis spp. & - & - & & - & - & - & + \\
\hline Total Score & & & & 10 & 7 & 11 & 12 \\
\hline
\end{tabular}

Key: + = present $-=$ absent 
Table 3: Pollution index of Algal species according to Palmer, (1969) at four sites of high Altitude wetland Dodi Tal of Garhwal Himalaya 2014 $-2015$.

\begin{tabular}{|c|c|c|c|c|c|c|c|}
\hline Bacillariophyceae & Order & Family & Pollution Index (Palmer1969) & S1 & $\mathbf{S 2}$ & S3 & S4 \\
\hline Closteriopsis longissima Lemmermann 1899 & & & - & - & - & + & + \\
\hline Cocconeis placentula Ehrenberg 1838 & Pennales & Acanthaceae & - & + & + & + & + \\
\hline Cymbella bengalensis Grun, 1875. & Pennales & Naviculaceae & - & + & + & + & + \\
\hline Cymbella cistuala ((Ehrenberg) O.Kirchner, 1878 & Pennales & Naviculaceae & - & - & - & + & + \\
\hline Diatoma vulgaris Bory 1824 & & & - & + & - & + & + \\
\hline fragilaria capucina Desmazières 1830 & Pennales & Fragilariaceae & - & + & + & + & + \\
\hline Nitzschia recta Hantzsch ex Rabenhorst 1862 & Pennales & Epithemiaceae & - & + & - & + & + \\
\hline Synedra ulna Ehrenberg 1832 & Pennales & Fragilariaceae & 3 & $+(3)$ & - & $+(3)$ & $+(3)$ \\
\hline Synedra acus Kützing 1844 & & & - & & & & \\
\hline Tabellaria fenestrata (Lyngbye) Kützing 1844 & - & - & - & + & + & + & + \\
\hline Tabellaria flocculosa (Roth) Kützing 1844 & - & - & - & + & + & + & + \\
\hline \multicolumn{8}{|l|}{ Chlorophyceae } \\
\hline Actinastrum hantzschii Lagerheim 1882 & - & Scenedesmaceae & - & + & - & + & - \\
\hline Ankistrodesmus falcatus (Corda) Ralfs 1848 & - & Oocystaceae & 3 & - & - & $+(3)$ & $+(3)$ \\
\hline Cladophora glomerata (Linnaeus) Kützing 1843 & Sphaeropleales & Sphaeropleaceae & - & + & - & + & - \\
\hline Pandorina morum (O.F.Müller) Bory 1824 & Volvocales & Volvocaceae & 3 & $+(3)$ & - & $+(3)$ & $+(3)$ \\
\hline Scenedesmus quadricauda Brébisson \& Godey 1835 & - & Scenedesmaceae & 4 & $+(4)$ & $+(4)$ & $+(4)$ & $+(4)$ \\
\hline Ulothrix zonata (F.Weber \& Mohr) Kützing 1833 & Ulotrichales & Ulotrichales & - & + & + & + & + \\
\hline Ulothrix tenerrima Kützing 1843 & Ulotrichales & Ulotrichales & - & + & - & + & + \\
\hline Volvox aureas Ehrenberg 1832 & Volvocales & Volvocaceae & - & + & - & + & + \\
\hline Xanthidium antilopaeum Kützing 1849 & Zygnamatales & Mesotaeniaceae & - & + & - & + & - \\
\hline \multicolumn{8}{|l|}{ Dinophyceae } \\
\hline Peridinium cinctum (O.F.Müller) Ehrenberg 1832 & Peridiniales & Peridiniaceae & - & - & - & + & + \\
\hline Total Score & & & & 10 & 4 & 13 & 13 \\
\hline
\end{tabular}

Table 4: Monthly and Seasonally variation in diversity index (Shannon-Wiener, 1964) for Algal taxa of high altitude wetland, Dodi T, Garhwal Himalaya for the period November 2014-October 2015

\begin{tabular}{|c|c|c|c|c|c|c|c|c|c|c|c|c|}
\hline Sites & Nov & Dec & Jan & Feb & Mar & Apr & May & Jun & Jul & Aug & Sep & Oct \\
\hline \multicolumn{10}{|c|}{ 2014-2015 } \\
\hline S1 & 4.21 & 3.71 & 3.27 & NA & NA & 4.07 & 4.14 & 3.98 & 3.46 & 3.73 & 3.89 & 4.26 \\
\hline S2 & 4.21 & 3.74 & 3.31 & NA & NA & 4.08 & 4.14 & 3.99 & 3.49 & 3.71 & 3.89 & 4.27 \\
\hline S3 & 4.23 & 3.71 & 3.41 & NA & NA & 4.15 & 4.15 & 4.03 & 3.59 & 3.75 & 3.86 & 4.26 \\
\hline S4 & 4.24 & 3.74 & 3.44 & NA & NA & 4.14 & 4.15 & 4.04 & 3.62 & 3.79 & 3.91 & 4.28 \\
\hline $\bar{x}_{\text {Diversity Index }}$ & 4.22 & 3.73 & 3.36 & NA & NA & 4.11 & 4.15 & 4.01 & 3.54 & 3.75 & 3.89 & 4.27 \\
\hline
\end{tabular}

\begin{tabular}{|c|c|c|c|c|c|}
\hline Sites & Winter & Spring & Summer & Monsoon & Autumn \\
\hline \multicolumn{5}{|c|}{$2014-2015$} \\
\hline S1 & 3.73 & NA & 4.07 & 3.59 & 4.08 \\
\hline S2 & 3.75 & NA & 4.07 & 3.60 & 4.08 \\
\hline S3 & 3.78 & NA & 4.11 & 3.67 & 4.06 \\
\hline S4 & 3.81 & NA & 4.11 & 3.67 & 4.06 \\
\hline $\bar{x}$ Diversity Index & 3.77 & NA & 4.09 & 3.63 & 4.07 \\
\hline
\end{tabular}

Table 5: Monthly and Seasonally variation in Jaccard evenness calculated for Algal taxa of high altitude wetland, Dodi Tal, Garhwal Himalaya for the period November 2014-October 2015

\begin{tabular}{|c|c|c|c|c|c|c|c|c|c|c|c|c|c|}
\hline Sites & Nov & Dec & Jan & Feb & Mar & Apr & May & Jun & Jul & Aug & Sep & Oct \\
\hline \multicolumn{10}{|c|}{$2014-2015$} \\
\hline S1 & 0.097 & 0.127 & 0.148 & NA & NA & 0.094 & 0.098 & 0.104 & 0.144 & 0.128 & 0.114 & 0.092 \\
\hline S2 & 0.097 & 0.124 & 0.150 & NA & NA & 0.094 & 0.100 & 0.105 & 0.145 & 0.132 & 0.114 & 0.094 \\
\hline S3 & 0.096 & 0.127 & 0.142 & NA & NA & 0.094 & 0.101 & 0.103 & 0.143 & 0.133 & 0.107 & 0.092 \\
\hline S4 & 0.096 & 0.124 & 0.143 & NA & NA & 0.094 & 0.101 & 0.103 & 0.144 & 0.130 & 0.105 & 0.093 \\
\hline $\bar{x}$ Jaccard evenness & 0.097 & 0.126 & 0.146 & NA & NA & 0.094 & 0.100 & 0.104 & 0.144 & 0.131 & 0.110 & 0.093 \\
\hline
\end{tabular}

\begin{tabular}{|c|c|c|c|c|c|}
\hline Sites & Winter & Spring & Summer & Monsoon & Autumn \\
\hline \multicolumn{7}{|c|}{ 2014-2015 } \\
\hline S1 & 0.124 & NA & 0.099 & 0.136 & 0.103 \\
\hline S2 & 0.124 & NA & 0.100 & 0.139 & 0.104 \\
\hline S3 & 0.122 & NA & 0.099 & 0.138 & 0.100 \\
\hline S4 & 0.121 & NA & 0.099 & 0.137 & 0.099 \\
\hline $\bar{x}_{\text {Jaccard evenness }}$ & 0.123 & NA & 0.099 & 0.137 & 0.101 \\
\hline
\end{tabular}




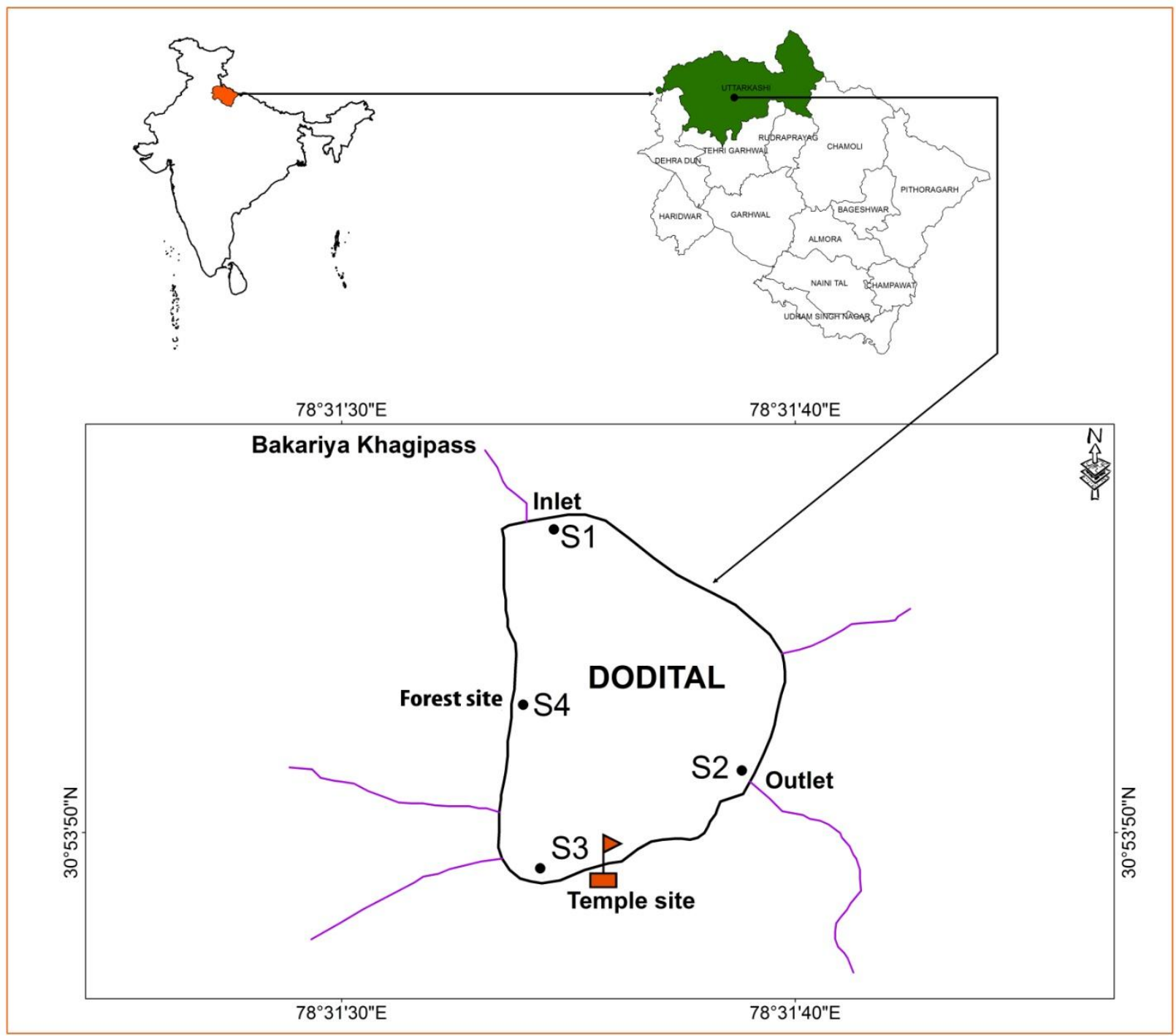

Fig 1: Location map of high altitude wetland Dodi Tal with sampling sites (S1, S2, S3, S4)

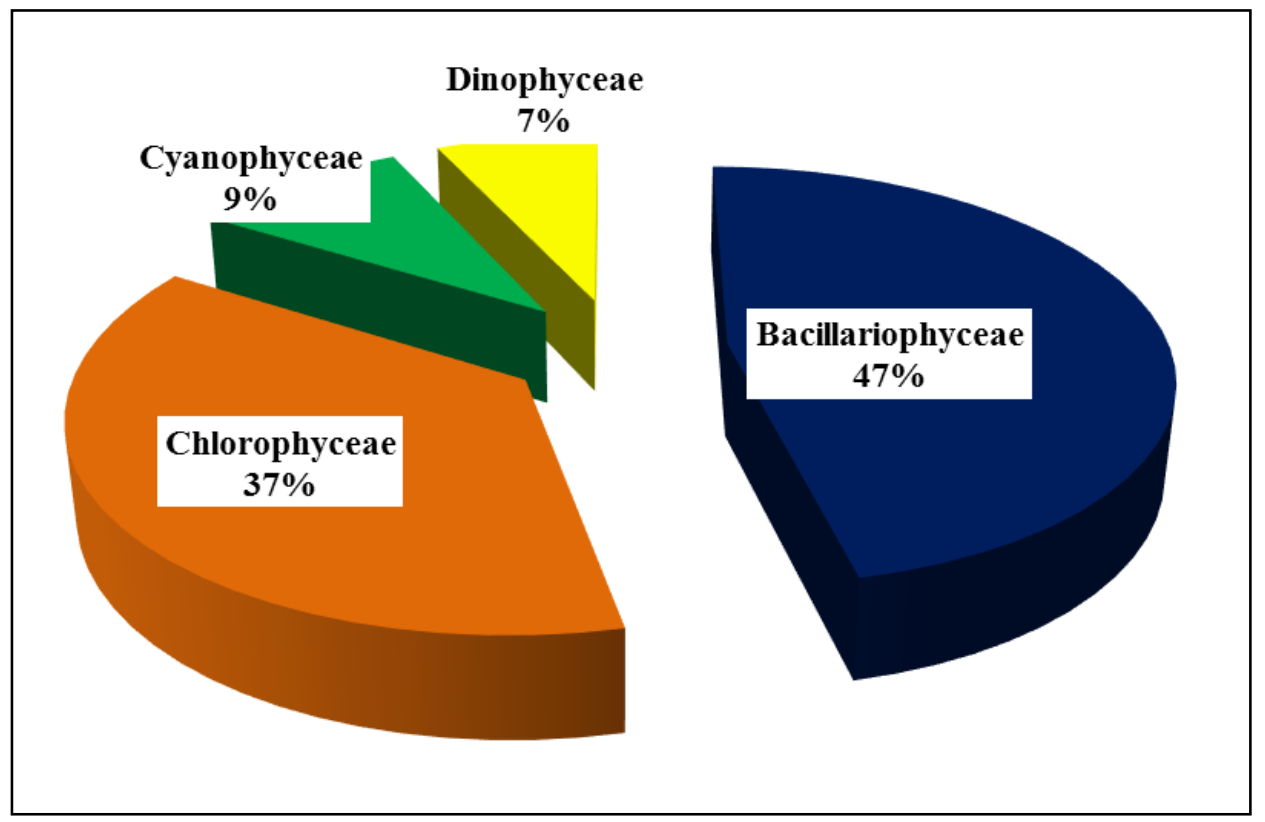

Fig 2: Percentage composition of algal taxa in Dodi Tal, Garhwal Himalaya (November 2014-October 2015) 


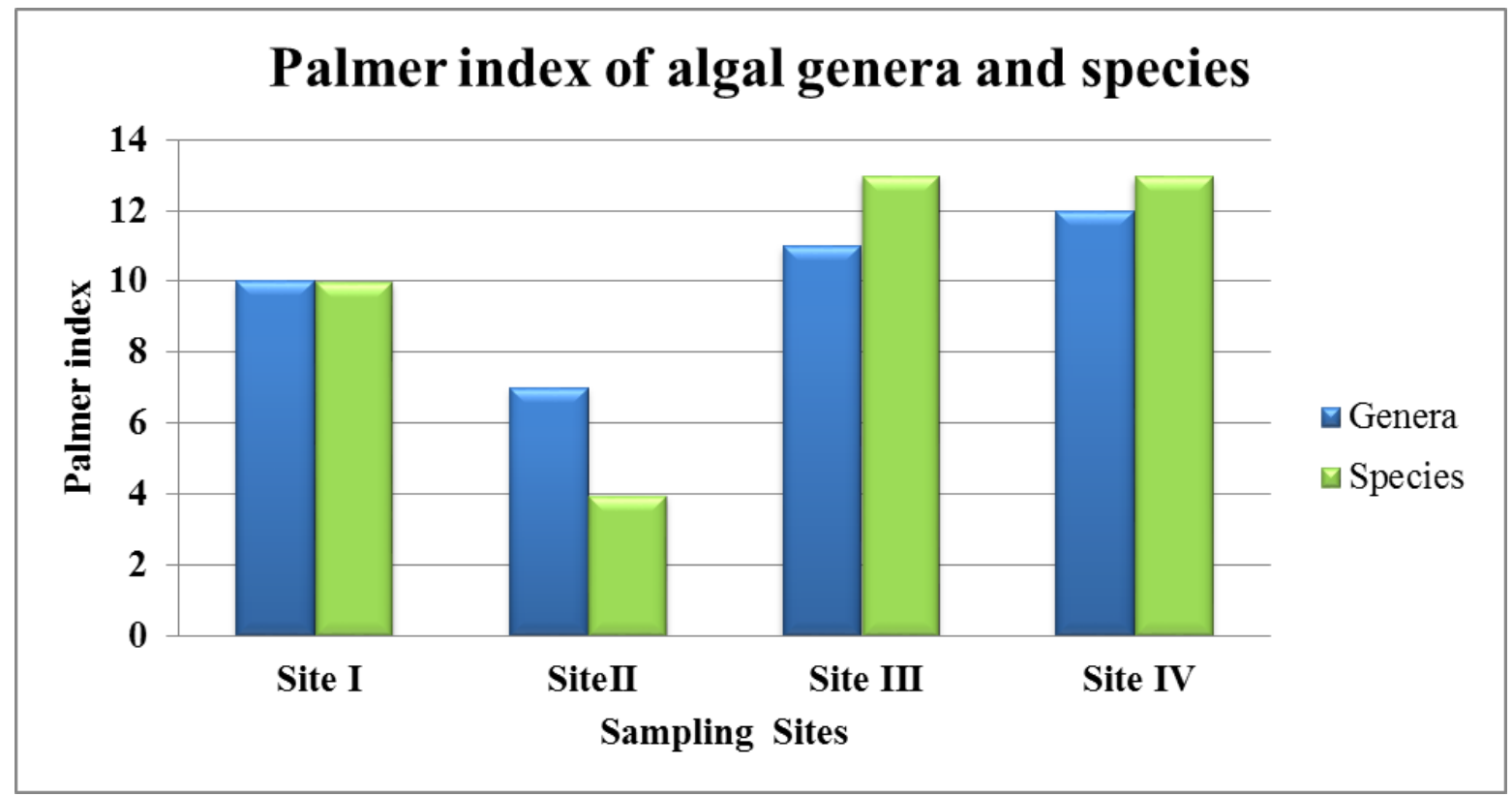

Fig 3: Pollution index score of algal genera and species at selected sampling sites of Dodi Tal for the period of November 2014Octobar 2015

\section{Acknowledgments}

One of the authors (Sushma Singh) is thankful to the University Grants Commission, New Delhi and H.N.B Garhwal University (A Central University) Srinagar Gharwal, Uttarakhand for providing her fellowship during the period of study.

\section{Reference}

1. APHA. Standard methods for the examination of water and wastewater. 21st Ed. American Public Health Association, APHA, AWWA, WEF, Washington, D. C. 2005, 1170.

2. Edmondson WT. Freshwater Biology, 2nd edition. New York and London, John Wiley and Sons, 1959, 45.

3. Ganai, AH, Parveen, S. Effect of physico-chemical conditions on the structure and composition of the phytoplankton community in Wular Lake at Lankrishipora, Kashmir. International Journal of Biodiversity and Conservation. 2014; 6(1):71-84.

4. Goma J, Rimet F, Cambra J, Hoffmann L, Ector L. Diatom communities and water quality assessment in Mountain Rivers of the upper Segre basin (La Cerdanya, Oriental Pyrenees). Hydrobiology. 2005; 551:209-225.

5. Jaccard P. The distribution of flora in the alpine zone. New phycology. 1942; 11:37-50.

6. Jindal R, Thakur RK, Uday, Bhan, Singh, Ahluwalia AS. Phytoplankton dynamics and species diversity in a shallow eutrophic, natural mid-altitude lake in Himachal Pradesh (India): role of physicochemical factors. Chemistry and Ecology. 2014; 30(4):328-338.

7. Kumar P, Wanganeo A, Sonaullah F, Wanganeo R. Limno-logical Study on two High Altitude Himalayan Ponds, Badrinath, Uttarakhand. Inter. J Ecosys. 2012; 2(5):103-111.

8. Loffler H. High Altitude Lakes in Mt. Everest Region," Verhandlungen des Internationalen Verein Limnologie, 1969; 17:373-385.

9. Munshi JD, Roy SP, Munshi JS. Manual of Freshwater Biota. Narendra Publishing House, Delhi, India, 2010, 1435.

10. Naik AA, Wanganeo A, Ishaq A, Najeeb A, Bhat.
Summer Limnology of a high mountain Lake 'Kailash Lake' Bhaderwah, Jammu and Kashmir. International Journal of Environmental Sciences. 2012; 3:3.

11. Palmer GA. composite rating of algae tolerating organic pollution. Journal of Phycology. 1969; 5:78-82.

12. Plafkin, JLMT, Barbour KD, Porter SK, Gross RM. Hughes. Rapid Assessment Protocols for Use in Streams \& Rivers: Benthic Macro invertebrates \& Fish. EPA:Washington, D.C. Rosenberg, D.M., V.H.Resh (eds). 1993. Freshwater Biomonitoring \& Benthic Macroinvertebrates. Chapman \& Hall: New York, NY, 1989.

13. Prescott GW. How to know the freshwater algae. C. Brown Company Publisher. Dubuque, Iowa, 1975.

14. Rawat MS, Sharma RC. Phytoplankton population of Garhwal Himalayn lake Deoria Tal, Uttranchal. J Ecophysiol. Occup. Hith. 2005; 5:73-76.

15. Shannon CE, Wiener W. The mathematical Theory of Communication. University of Illinois Press. Urbana, U.S.A, 1964.

16. Singh Y, Khattar JIS, Singh DP, Rahi P, Gulati A. Limnology and cyanobacterial diversity of high altitude lakes of Lahaul-Spiti in Himachal Pradesh, India. J Biosci. 2014a; 39:643-657.

17. Stevenson RJ, Pan Y. Assessing environmental conditions in rivers and streams with diatoms. In: Stoermer, E.F., Smol, J.P. (eds), The Diatoms: Applications for the Environment and Earth Science. Cambridge University Press, Cambridge. 1999, 57-85.

18. Willhm JL, Dorris T. Biological Parameters of water quality criteria Biosciences. 1968; 18:477-481. 